Published as The Evolution of Marine Spatial Planning in New Zealand: Past Present and Possible Future" 31 (2016) International Journal of Marine and Coastal Law 652 - 689

\title{
The Evolution of Marine Spatial Planning in New Zealand: Past Present and Possible Future
}

\author{
Karen N. Scott ${ }^{\star}$ \\ Professor, School of Law \\ University of Canterbury, New Zealand \\ Karen.Scott@canterbury.ac.nz
}

This manuscript has not been published elsewhere and has not been submitted for consideration by any other journal.

Key Words

Marine Spatial Planning (MSP), New Zealand, ocean governance, principles

\begin{abstract}
This article explores marine spatial planning (MSP) as it is being developed in New Zealand. It breaks down the global concept of MSP into six core principles and evaluates the extent to which New Zealand implements these principles within its ocean governance regime. The article concludes with brief recommendations for developing MSP in New Zealand in the future.
\end{abstract}

\section{Introduction}

Marine spatial planning (MSP) has become the most widely applied tool for implementing ecosystem-based integrated management in the marine environment over the last decade. ${ }^{1}$ Building on the preamble to the 1982 United Nations Convention on the Law of the Sea $(\mathrm{UNCLOS})^{2}$ that recognised the need to manage ocean space as an interrelated whole, the concept of area-based integrated management has been endorsed at the international level by the parties to the 1992 Convention on Biological Diversity, ${ }^{3}$ the UN Secretary General ${ }^{4}$ and the UN General Assembly. ${ }^{5}$ The concept of MSP in particular emerged as a post Rio +20 focal point with the creation of a project entitled Global Partnership and Capacity Building for Ecosystem-Based Management of Oceans and Coasts - Pursuing Compatible Objectives for Sustainable Development through Integrated Spatial Planning, Management and Policies. ${ }^{6}$ At the national level, MSP has been adopted by over 30 states including the UK and Australia. ${ }^{7}$ By contrast, New Zealand has not expressly endorsed

\footnotetext{
- Professor of Law, University of Canterbury. This article is part of a broader project on ocean governance in New Zealand supported by the New Zealand Law Foundation. The author would like to acknowledge the Foundation for their support associated with the research of this article.

${ }^{1}$ G Carneiro, 'Evaluation of marine spatial planning' (2013) 37 Marine Policy 214 - 229, at p. 214.

2 United Nations Convention on the Law of the Sea (Montego Bay, 10 December 1982, in force 16 November 1994) 1833 UNTS 396.

${ }^{3}$ Convention on Biological Diversity (Rio, 5 June 1992, in force 29 December 1993) 31 ILM (1992) 818. See CBD Decision X/29 Marine and coastal biodiversity (2010), [15]; CBD Decision XI/18 Marine and coastal biodiversity: sustainable fisheries and addressing adverse impacts of human activities, voluntary guidelines for environmental assessment and marine spatial planning (2012); and Synthesis Document on the Experience and the Use of Marine Spatial Planning (UNEP/CBD/SBSTTA/16/INF/18) (2 April 2012).

${ }^{4}$ Report of the Secretary General on Oceans and the law of the sea, A/68/71/Add.1 (9 September 2013) at [80] and [103-104].

5 The Future we Want A/RES/66/288 (27 July 2012) at[148].

${ }^{6}$ See http://www.uncsd2012.org/index.php?page=view\&type=1006\&menu=153\&nr=501

${ }^{7}$ See generally, B. Cicin-Sain, D. L. VanderZwaag and M. Balgos (eds), Routledge Handbook of National and Regional Ocean Policies (London and New York, Routledge 2015).
} 
MSP as a tool of oceans governance. In this article New Zealand practice in marine management is assessed against six core principles of MSP in order to evaluate the extent to which MSP is emerging within or, at the very least, is supportive of ocean governance within New Zealand's maritime zone. These principles comprise: area-based ecosystem management; principled anticipatory management; integrated management of multiple activities; precaution; review, monitoring and adaptive management; and public engagement. This article will conclude with selected recommendations to build upon the foundations already laid by New Zealand's existing legislative and policy framework in order to further develop a MSP approach to marine governance.

\section{New Zealand's Marine Environment}

New Zealand's exclusive economic zone (EEZ) is the fifth largest in the world, comprising more than 4 million $\mathrm{km}^{2},{ }^{8} 15$ times the terrestrial land area of New Zealand. ${ }^{9}$ In 2008, 1.7 million $\mathrm{km}^{2}$ of extended continental shelf was added to New Zealand's maritime zone ${ }^{10}$ increasing the marine to land ratio from 15 to 21 . New Zealand's maritime zone is as ecologically diverse as it is geographically dispersed, extending from the sub-tropical waters surrounding Raoul Island $1000 \mathrm{~km}$ north of the mainland to the sub-Antarctic waters surrounding Campbell Island $640 \mathrm{~km}$ south of Bluff. ${ }^{11}$ The 17,135 marine species described to date ${ }^{12}$ represent nearly 80 percent of New Zealand's entire biodiversity ${ }^{13}$ and 44 percent of that marine biodiversity is endemic. ${ }^{14}$ Almost 50 percent of the world's cetaceans are found within New Zealand's waters ${ }^{15}$ and nearly one quarter of the world's seabird species breed on the New Zealand coast and offshore islands. ${ }^{16}$ In contrast to the crowded waters of Asia and Europe, New Zealand's maritime zone experiences fewer pressures from the competing demands of industry and shipping. Fisheries, which are generally well managed under New Zealand's quota management system, comprise the most important economic activity within the marine environment and contributed NZ\$1,419 million to exports in 2014. ${ }^{17}$ New Zealand has a small offshore oil and gas industry, which contributed NZ\$1,400 million to New Zealand exports in 2014, ${ }^{18}$ generating approximately $\$ 400$ million a year in royalties. ${ }^{19}$ More generally, New Zealanders value the coastal and marine environment for cultural, spiritual and recreational purposes.

\footnotetext{
${ }^{8}$ Land Information New Zealand available at http://www.linz.govt.nz/about-linz/what-weredoing/projects/new-zealand-continental-shelf-project/map-continental-shelf; accessed 1 August 2016. ${ }_{9}^{9}$ DP Gordon et al, 'Marine Biodiversity of Aotearoa New Zealand' (2010) 5(8) PLoS ONE e10905 at p. 1.

${ }^{10}$ Land Information New Zealand (n 8).

${ }^{11}$ DP Gordon et al (n 9).

${ }^{12} \mathrm{DP}$ Gordon et al (n 9) at p. 1

${ }_{13}$ Ministry for the Environment, Environment New Zealand 2007 (Ministry for the Environment, Wellington 2007) (hereinafter, Environment New Zealand 2007) at p. 316.

${ }_{14}$ Ibid., at p. 316.

${ }^{15}$ Ministry for the Environment and Statistics New Zealand, New Zealand's Environmental Reporting Series: Environment Aotearoa 2015 (Ministry for the Environment, Wellington, 2015) (hereinafter, Environment Aotearoa 2015) at p. 93.

16 Ibid.

17 Ibid at p. 92.

${ }^{18}$ Ibid at p. 93.

${ }^{19}$ Ibid.
} 
According to the Global Ocean Health Index ${ }^{20}$ in 2016 New Zealand ranked 65 out of $221 \mathrm{EEZs}^{21}$ with an overall score of 72 out of 100 just ahead of the global average of $70 .{ }^{22}$ This is significantly behind Australia, ranked in 2016 at 11 with an overall score of 80 out of $100,^{23}$ behind the UK, which is ranked 52 in 2016 with an overall score of 73 out of $100^{24}$ and slightly ahead of Canada, ranked 76 with an overall score of 71 out of $100 .{ }^{25}$ A recent report on the state of the New Zealand environment ${ }^{26}$ noted that more than 25 percent of New Zealand's indigenous marine mammals are threatened with extinction and the Māui dolphin is critically endangered with only an estimated 55 individuals of more than one year old remaining in the wild. ${ }^{27}$ Ninety percent of indigenous seabirds breeding in New Zealand are threatened with or at risk of extinction ${ }^{28}$ with bycatch as the most significant albeit now decreasing threat. ${ }^{29} 192$ million tonnes of soil comprising 1.5 percent of global sediment loss enters New Zealand's ocean environment annually, ${ }^{30}$ a remarkable statistic given that New Zealand constitutes less than 0.2 percent of the global land area. ${ }^{31}$ The most serious long-term threat to New Zealand's marine environment identified in the report is climate change ${ }^{32}$ with rises in sea-level and ocean acidity already recorded. ${ }^{33}$

\section{Marine Spatial Planning: Global and Regional Trends}

Although there is no one globally accepted definition of the concept, UNESCO has defined MSP as 'a public process of analyzing and allocating the spatial and temporal distribution of human activities in marine areas to achieve ecological, economic and social objectives that are usually specified through a political process. ${ }^{34}$ Integration has been described as an essential feature of modern oceans governance ${ }^{35}$ which, by departing from a sectoral, typically fragmented approach to regulation, ${ }^{36}$ naturally supports area or placebased management. ${ }^{37}$ But whilst marine spatial planners typically use marine protected

\footnotetext{
${ }^{20}$ See http://www.oceanhealthindex.org; accessed 1 August 2016. For the background to this project see BS Halpern, C Longo, D Hardy et al, 'An index to assess the health and benefits of the global ocean' (2012) 488 Nature 615 - 520.

21 http://www.oceanhealthindex.org/region-scores/scores/new-zealand; accessed 1 August 2016.

22 Ibid.

${ }^{23}$ http://www.oceanhealthindex.org/region-scores/scores/australia; accessed 1 August 2016.

$24 \mathrm{http}$ // www.oceanhealthindex.org/region-scores/scores/united-kingdom; accessed 1 August 2016.

$25 \mathrm{http}: / /$ www.oceanhealthindex.org/region-scores/scores/canada; accessed 1 August 2016.

26 Environment Aotearoa 2015 (n 15).

27 Environment Aotearoa 2015 (n 15), at p. 97.

28 Environment Aotearoa 2015 (n 15), at p. 102.

${ }^{29}$ Environment Aotearoa 2015 (n 15), at p. 97. Between 2001 and 2014 an estimated 55,000 seabirds were caught in fishing gear as bycatch.

30 Environment Aotearoa 2015 (n 15), at p. 99.

31 Environment Aotearoa 2015 (n 15).

32 Environment Aotearoa 2015 (n 15), at p. 94.

33 The sea level around the coast of New Zealand has risen by between $1.31 \mathrm{~mm}$ and $2.14 \mathrm{~mm}$ and a statistical increase in ocean acidity in New Zealand's subantarctic has been recorded. See Environment Aotearoa 2015 (n 15) at pp. 94 and 95.

${ }^{34} \mathrm{C}$ Ehler and F Douvere, 'Marine Spatial Planning: A Step-by-Step Approach Toward Ecosystem-Based Management' Intergovernmental Oceanographic Commission and Man and the biosphere Programme, IOC Manual and Guides No. 53, ICAM Dossier No. 6 (Paris), 2009 at p. 18.

${ }^{35} \mathrm{R}$ Barnes, 'The Law of the Sea Convention and the Integrated Regulation of the Oceans' (2012) 27 The International Journal of Marine and Coastal Law 859 - 866 at p. 859.

${ }^{36}$ JA Ekstrom, OR Young, SD Gaines et al, 'A tool to navigate overlaps in fragmented ocean governance' (2009) 33 Marine Policy $532-535$ at p. 532.

${ }^{37}$ RK Craig, Comparative Ocean Governance. Place-Based Protections in an Era of Climate Change (Edward Elgar, Cheltenham, 2012) at p. 94.
} 
areas (MPAs) to achieve key objectives, such as protecting particularly vulnerable ecosystems, MSP is more than mere area protection. ${ }^{38}$ Similarly, MSP goes beyond the goal of integrating the management of multiple activities in accordance with high level objectives and principles, ${ }^{39}$ and anchors the tool firmly within the ecosystem approach, ${ }^{40}$ commonly utilizing spatial zoning techniques. Moreover, marine spatial planning is a tool of sufficient flexibility to enable it to be adapted to achieve multiple objectives and to respond to regional needs. ${ }^{41}$

One of the earliest examples of $\mathrm{MSP}^{42}$ was adopted by Australia in respect of the Great Barrier Reef. The 1975 Great Barrier Reef Marine Park Act ${ }^{43}$ facilitates the conservation and ecological sustainable use of the entire park as an integrated whole and proactively manages activities taking place therein through a system of multiple use zoning. ${ }^{44}$ More generally, integrated and spatial planning are key elements of Australia's Oceans Policy adopted in 1998. ${ }^{45}$ Marine Bioregion Plans (MBP) (which replaced the regional marine plans in 2005 ${ }^{46}$ ) have, in contrast to Australia's Oceans Policy more generally, a statutory basis: section 176 of the Environment Protection and Biodiversity Conservation Act (EPBC) 1999. ${ }^{47}$ Each bioregional plan must set out the components of biodiversity located with the region, specify economic and social values and establish objectives and priorities for biodiversity conservation as well as mechanisms for involving the community in the implementation of the plan and for monitoring and reviewing the plan. ${ }^{48}$ So far four plans have been adopted ${ }^{49}$ and all set out relatively high-level goals and priorities designed to assist and inform decision-makers. None of the plans have legislative effect however and, notably the plans apply to waters under Commonwealth jurisdiction only and, consequently, are not entirely ecosystem based. ${ }^{50}$ Moreover, the more general tension between the Commonwealth and states/ territory has made progress in developing MSP slow. ${ }^{51}$ Importantly, the location of Australia's MSP requirements in the 1999 EPBC

\footnotetext{
${ }^{38}$ See GW Allison, J Lubchenco and MH Carr, 'Marine Reserves are Necessary but not Sufficient for Marine Conservation' (1998) 8(1) Supplement: Ecosystem Management for Sustainable Marine Fisheries S79 - 92. ${ }^{39}$ On the relationship between integrated management and MSP see KN Scott 'Integrated Oceans Management: A New Frontier in Marine Environmental Protection' in DR Rothwell, AG Oude Elferink, KN Scott and T Stephens (eds) The Oxford Handbook on the Law of the Sea (Oxford University Press, Oxford 2015) $463-490$.

40 See F Douvere, 'The importance of marine spatial planning in advancing ecosystem-based sea use management' (2008) 32 Marine Policy 762 - 771.

${ }^{41}$ For an overview of MSP global practice see S Jay, W Flannery, J Vince et al, 'International Progress in Marine Spatial Planning' (2013) 27 Ocean Yearbook 171 - 212 at p. 173.

${ }^{42}$ For an overview of MSP as adopted globally see http://www.unesco-iocmarinesp.be/msp around the world; accessed 1 August 2016.

43 Great Barrier Reef Marine Park Act 1975 No. 85, 1975.

${ }^{44}$ See JC Day, 'Zoning - lessons from the Great Barrier Reef Marine Park' (2002) 45 Ocean and Coastal Management 139 - 156.

45 Australia's Oceans Policy 1998 is available at: http://www.environment.gov.au/archive/coasts/oceanspolicy/publications/pubs/policyv1.pdf; accessed 1 August 2016. For an overview of Australian oceans policy see M Tsamenyi and R Kenchington, 'Australian Oceans Policymaking' (2012) 40 Coastal Management 119 - 132 .

46 Ibid., at p. 129.

${ }^{47}$ Environment Protection and Biodiversity Conservation Act (EPBC) 1999 No. 91, 1999.

48 Ibid., section 176(4).

49 Marine bioregional plan for the North-west Marine Region; Marine bioregional plan for the North Marine Region; Marine bioregional plan for the South-west Marine Region; Marine bioregional plan for the Temperate East Marine Region. A profile for the South-east marine region has also been developed. The four plans and one profile can be accessed at: http://www.environment.gov.au/marine/marinebioregional-plans; accessed 1 August 2016.

${ }^{50}$ M Tsamenyi and R Kenchington (n 45) at p. 126.

${ }^{51}$ M Tsamenyi and R Kenchington ( $\mathrm{n}$ 45) at p. 130. On the Australian experience see V Sakell, 'Operationalizing integrated coastal and oceans management in Australia. The Challenges' in DR Rothwell
} 
Published as The Evolution of Marine Spatial Planning in New Zealand: Past Present and Possible Future" 31 (2016) International Journal of Marine and Coastal Law 652 - 689

Act has entrenched the Australian approach of using spatial planning to support essentially conservationist ends. ${ }^{52}$

Similar motivation with respect to the adoption of MSP can be found in the approaches of Canada and the United States. In contrast to Australia, Canada's Oceans Strategy, adopted in 2002, ${ }^{53}$ has a legislative foundation in the 1996 Oceans Act $^{54}$ and is managed by an overarching coordinating agency: Fisheries and Oceans Canada. The Strategy rests on the principles of sustainable development, integrated management and the precautionary approach and whilst it does not explicitly endorse MSP it emphasises integrated planning for five large ocean management areas (LOMAS) identified under the Act. ${ }^{55}$ Progress over the last decade has been slow with the most advanced integrated management plan being developed for the Eastern Scotian Shelf region. ${ }^{56}$ However, integrated management plans have now been adopted for the Beaufort Sea (2009), ${ }^{57}$ the Placentia Bay - Grand Banks Integrated Management Area (2012), ${ }^{58}$ the Gulf of St. Lawrence $(2013)^{59}$ and the Scotian Shelf/ Atlantic Coast/ Bay of Fundy region (2014) ${ }^{60}$ (replacing the Eastern Scotian Shelf Integrated Management (ESSIM) Initiative). A draft integrated management plan for the Pacific North Coast Integrated Management Area was produced in 2013. ${ }^{61}$ All plans emphasise the ecosystem approach, endorse a collaborative and inclusive approach to planning and implementation and support the creation of a network of MPAs. All seek to address at varying levels the management of human

and DL VanderZwagg (eds), Toward Principled Oceans Governance. Australian and Canadian approaches and challenges (Routledge, Oxon, 2006) 72 - 98; E Foster, M Haward and S Coffen-Smout, 'Implementing integrated oceans management: Australia's south east regional marine plan (SERMP) and Canada's eastern Scotian shelf integrated management (ESSIM) initiative' (2005) 29 Marine Policy 391 - 405; G Wescott, 'Stimulating Vertical Integration in Coastal Management in a Federated Nation: The Case of Australian Policy Reform' (2009) 37 Coastal Management 501 - 513; and DR Rothwell, 'Environmental Integration and Coastal and Marine Law' in R Baird and DR Rothwell Australian Coastal and Marine Law (The Federation Press, Sydney, 2011) $348-372$.

52 S Jay, W Flannery, J Vince et al, (n 40) at p. 173.

53 Available at: http://www.dfo-mpo.gc.ca/oceans/documents/cos-soc/cos-soc-eng.pdf; accessed 1 August 2016.

54 Oceans Act S.C. 1996 c. 31.

55 TL McDorman and A Chircop, 'Canada's Oceans Policy Framework: An Overview' (2012) 40 Coastal Management 133 - 144 at p.142. See more generally A Chircop and L Hilderbrand, 'Beyond the buzzwords: a perspective on integrated coastal and ocean management in Canada' in DR Rothwell and DL

VanderZwagg (eds) (n 51) at pp. $19-71$.

56 The Eastern Scotian Shelf Integrated Management Initiative (ESSIM) operated between 2007 and 2012. Information on the ESSIM can be found here: http://www.inter.dfo-

mpo.gc.ca/Maritimes/Oceans/OCMD/ESSIM/Strategic-Plan/ESSIM-Plan; accessed 1 August 2016. See also E Foster, M Haward and S Coffen-Smout (n 51); RJ Rutherford, GJ Herbert and S Coffen-Smout, 'Integrated ocean management and the collaborative planning process: the Eastern Scotian Shelf Integrated Management (ESSIM) Initiative' (2005) 29 Marine Policy 75 - 83; T Hall, M MacLean, S Coffen-Smout et al, 'Advancing objectives-based, integrated ocean management through marine spatial planning: current and future directions on the Scotian Shelf off Nova Scotia, Canada' (2011) 15 J Coast Conserv 247 - 255; W Flannery \& MÓ Cinnéide, 'Deriving Lessons Relating to Marine Spatial Planning from Canada's Eastern Scotian Shelf Integrated Management Initiative’ (2012) 14 Journal of Environmental Policy \& Planning 97 - 117. ${ }^{57}$ Available at: http://www.dfo-mpo.gc.ca/Library/350719.pdf; accessed 1 August 2016.

58 Available at: http://www.dfo-mpo.gc.ca/oceans/management-gestion/placentia-bay-grand-bankseng.html; accessed 1 August 2016.

59 Available at: http://www.qc.dfo-mpo.gc.ca/gestionmanagement/doc/2013 12 16 FINAL_ANGLAIS web.pdf; accessed 1 August 2016.

${ }^{60}$ Available at: http://www.dfo-mpo.gc.ca/oceans/management-gestion/scotian-shelf-bay-of-fundyeng.html; accessed 1 August 2016.

${ }^{61}$ Available at: http://www.pncima.org/media/documents/pdf/draft-pncima-plan-may-27--2013.pdf; accessed 1 August 2106. See also NC Ban, KM Bodtker, D Nicolson et al, 'Setting the stage for marine spatial planning: Ecological and social data collation and analyses in Canada's Pacific waters' (2013) 39 Marine Policy $11-20$. 
activities and the importance of supporting sustainable development of the regions. In the United States whilst MSP has long been implemented in some regions ${ }^{62}$ it has been developed at the national level much more recently than Canada. In 2010 MSP was formally endorsed as a guiding principle for ocean management in the Final Recommendations for the Interagency Ocean Policy Task Force. ${ }^{63}$ The National Ocean Council, which was also created in 2010, is charged with developing regional coastal and marine spatial plans for nine planning areas, working with states as well as federally recognized tribes. The Council released the National Ocean Policy Implementation Plan ${ }^{64}$ and the Marine Planning Handbook ${ }^{65}$ in 2013 but planning is at a very early stage of development.

In contrast to Australia, Canada and the US, MSP in Europe is emerging as a tool with the primary focus of supporting sustainable development and managing competing and conflicting maritime activities such as offshore wind-farms. ${ }^{66}$ In the UK MSP was introduced as the central management tool for British waters by virtue of the 2009 Marine and Coastal Access Act. ${ }^{67}$ The 2009 Act provides for the adoption of a Marine Policy Statement (MPS) for the UK, ${ }^{68}$ which sets out the vision for marine planning and a guide to the process and content of regional marine plans. In respect of English and Welsh waters, the Act created a central executive agency, the Marine Management Organisation (MMO), with a mandate to manage planning and licensing of all activities (with the exception of large infrastructure projects), including fishing (within the territorial sea). ${ }^{69}$ Equivalent legislation has been adopted for Scotland and Northern Ireland. ${ }^{70}$ The UK EEZ, finally in force from $2014,{ }^{71}$ is divided into 11 planning zones for England and Wales ${ }^{72}$ and 11 planning zones for Scotland. ${ }^{73} \mathrm{~A}$ marine plan for Northern Ireland is currently under development. Planning for these regions is on-going and the aim is to complete all plans by $2021 .^{74}$ The British approach to MSP is in part driven by the broader

\footnotetext{
62 Including Washington, Oregon, Florida and Massachusetts.

${ }^{63}$ Final Recommendations of the Interagency Ocean Policy Task Force (July 19 2010) available at: http://www.whitehouse.gov/files/documents/OPTF FinalRecs.pdf; accessed 1 August 2016. Adopted by Executive Order 13547 on 19/7/10. See: http://www.whitehouse.gov/the-press-office/executive-orderstewardship-ocean-our-coasts-and-great-lakes; accessed 1 August 2016.

${ }^{64}$ Available at: https://www.whitehouse.gov/sites/default/files/national ocean policy implementation plan.pdf. ${ }^{65}$ Available at: https://www.whitehouse.gov//sites/default/files/final marine planning handbook.pdf; accessed 1 August 2016.

${ }^{66}$ S Jay, W Flannery, J Vince et al (n 41) at p. 174. See also M Young, Building the Blue Economy: The Role of Marine Spatial Planning in Facilitating Offshore Renewable Energy Development' (2015) 30 International Journal of Marine and Coastal Law 148 - 173.

${ }^{67}$ Marine and Coastal Access Act 2009 c. 23, Part 3.

${ }^{68}$ The MPS was adopted in 2011 and is available at: https://www.gov.uk/government/uploads/system/uploads/attachment data/file/69322/pb3654-marinepolicy-statement-110316.pdf; accessed 1 August 2016.

${ }^{69}$ Equivalent legislation has been adopted for and for Northern Ireland: Reference.

${ }^{70}$ Scotland in the Marine (Scotland) Act 2010 asp 5 and The Marine Act (Northern Ireland) 2013 c. 10.

712009 Marine and Coastal Access Act, section 41 and Marine Management

The Exclusive Economic Zone Order 2013 (SI 2013/ 31/61).

72 See:

https://www.gov.uk/government/uploads/system/uploads/attachment data/file/325688/marine plan a reas.pdf; accessed 1 August 2016.

${ }^{73}$ See: http://www.gov.scot/Resource/0047/00476907.pdf; accessed 1 August 2016.

${ }^{74}$ See generally S Kidd, 'Rising to the integration ambitions of Marine Spatial Planning: Reflections from the Irish Sea' (2013) 39 Marine Policy 273 - 282; HD Smith, RC Ballinger \& TA Stojanovic, 'The Spatial Development Basis of Marine Spatial Planning in the United Kingdom' (2012) 14 Journal of Environmental Policy and Planning 29 - 47; S Fletcher, E McKinley, K Buchan et al, 'Effective Practice in Marine Spatial Planning: A Participatory Experience in Southern England' (2013) 39 Marine Policy 341 - 348.
} 
Published as The Evolution of Marine Spatial Planning in New Zealand: Past Present and Possible Future" 31 (2016) International Journal of Marine and Coastal Law 652 - 689

European mandate implemented ${ }^{75}$ through the Integrated Maritime Policy adopted in $2007,{ }^{76}$ the Marine Strategy Framework Directive adopted in $2008^{77}$ and, most recently, the Framework for Marine Spatial Planning Directive adopted in $2014 .{ }^{78}$ As a cornerstone of the EU approach to integrated maritime policy ${ }^{79}$ MSP has unsurprisingly has been adopted by an increasing number of European states including Belgium, ${ }^{80}$ Germany, the Netherlands ${ }^{81}$ and Ireland. ${ }^{82}$

European MSP has also been driven by separate but parallel initiatives within regional seas bodies. In the Mediterranean where significant pressures result from coastal development the focus has been on integrating coastal and marine planning through integrated coastal zone management (ICZM), culminating in the adoption of a Protocol to the 1995 Barcelona Convention ${ }^{83}$ on ICZM in the Mediterranean in $2008 .^{84}$ Like MSP, ICZM internalises an ecosystem approach to coastal/ marine planning ${ }^{85}$ and seeks to integrate the management of multiple activities ${ }^{86}$ but unlike MSP, it is seldom used to allocate coastal and marine space to activities. ${ }^{87}$ By contrast, in the North East Atlantic and the Baltic Sea the allocation of marine space between competing activities such as oil and gas exploitation, fishing and offshore wind-farms has driven the development of MSP in both regions. The Baltic region in particular, has been highlighted as the best example of regional MSP. ${ }^{88}$ A joint co-chaired working group on MSP was established by the Helsinki Commission (HELCOM) ${ }^{89}$ and the Vision and Strategies around the Baltic Sea (VASAB) in 2010, which, issued in that same year, a set of 10 principles designed to guide

\footnotetext{
75 See generally, T Koivurova, 'Integrated Maritime Policy of the European Union: Challenges, Successes, and Lessons to Learn' (2012) 40 Coastal Management 161 - 171.

${ }^{76}$ Communication from the Commission to the European Parliament, the Council, the European Economic and Social Committee and the Committee of the Regions - An Integrated Maritime Policy for the European Union $\operatorname{COM}(2007) 575$ final (10/10/07).

77 Directive 2008/56/EC of the European Parliament and of the Council of 17 June 2008 establishing a framework for community action in the field of marine environmental policy (Marine Strategy Framework Directive) OJ L 164, 25.6.2008, p. 19-40.

${ }^{78}$ Directive 2014/89/ EU of the European Parliament and of the Council of 23 July 2014 establishing a framework for marine spatial planning OJ L 257, 28.8.2014, p. 135-145.

${ }^{79}$ See R Churchill, 'The European Union and the Challenges of Marine Governance: From Sectoral Response to Integrated Policy' in D Vidas and PJ Schei (eds), The World Ocean in Globalisation. Climate Change, Sustainable Fisheries, Biodiversity, Shipping, Regional Issues (Martinus Nijhoff, Leiden, 2011) 395 - 436; T Koivurova (n 75); W Qiu and PJS Jones, 'The emerging policy landscape for marine spatial planning in Europe' (2013) 39 Marine Policy 182 - 190; and N Schaefer and V Barale, 'Maritime spatial planning: opportunities and challenges in the framework of the EU integrated maritime policy' (2011) 15 J Coast Conserv $237-245$.

${ }^{80}$ See F Douvere, F Maes, A Vanhulle et al, 'The role of marine spatial planning in sea use management: The Belgium case' (2007) 31 Marine Policy 182 - 191.

${ }^{81}$ See P Drankier, 'Embedding Maritime Spatial Planning in National Legal Frameworks' (2012) 14 Journal of Environmental Policy and Planning $7-27$ at pp. $16-19$.

82 W Flannery and MÓ Cinnéide, 'Marine spatial planning from the perspective of a small seaside community in Ireland' (2008) 32 Marine Policy 980 - 987.

${ }^{83}$ Convention for the Protection of the Marine Environment and the Coastal Region of the Mediterranean 1995, in force 9 July 2004.

84 Protocol on Integrated Coastal Zone Management in the Mediterranean, in force 24 March 2011.

${ }^{85}$ MF Frost, 'The convergence of Integrated Coastal Zone Management and the ecosystems approach' (2009) 52 Ocean and Coastal Management 294 - 306 at p. 301.

86 B Cicin-Sain, RW Knecht, A Vallega et al, 'Education and training in integrated coastal management: lessons from the international arena' (2000) 43 Ocean and Coastal Management $291-330$ at p. 292.

${ }^{87}$ Stephen Jay, Wesley Flannery, Joanna Vince et al (n 41) at p. 176.

88 Synthesis Document on the Experience and the Use of Marine Spatial Planning

(UNEP/CBD/SBSTTA/16/INF/18) (2 April 2012) at 10. See generally, H Backer, 'Transboundary maritime spatial planning: a Baltic Sea perspective' (2011) 15 Journal of Coast Conserv 279 - 289.

${ }^{89}$ Established under the 1992 Convention on the Protection of the Marine Environment of the Baltic Sea Area, in force 17 January 2000.
} 
Baltic Sea broad-scale maritime spatial planning. ${ }^{90}$ A Regional Baltic MSP Roadmap for 2013 - 2020 was adopted in 2013 setting out the steps necessary to achieve MSP in the region including targets for drafting detailed guidelines relating to cooperation, public participation and the implementation of the ecosystem approach. ${ }^{91}$

\section{Marine Spatial Planning: Six Core Criteria}

There is no one correct approach to MSP and overarching multiple guidelines exist at the global ${ }^{92}$ and at the regional level. ${ }^{93}$ Nevertheless, common to most if not all articulations of MSP are six core principles and it is these principles against which the practice of New Zealand will be assessed for the purposes of this article.

First, '[s] upport for MSP rests on the proposition that integrated management of areas subject to multiple claims has to start by ordering these claims in space and time... ${ }^{94}$ MSP thus focuses on place rather than sector and is based on a practical implementation of the ecosystem approach to ocean management. ${ }^{95}$ The concept of 'place' in the marine environment is necessarily more complex than its terrestrial counterpart. ${ }^{96}$ The ocean and seabed is physically and temporally a profoundly dynamic environment and its three dimensional nature permits the surface, water column and seabed to be used separately but simultaneously. ${ }^{97}$ The idea of managing relationships is therefore as fundamental as the notion of managing a defined space. As Stephen Jay has argued 'the emphasis is less upon space as a pre-existing plane upon which things can be located, arranged and mapped, and more upon space as generated by inter-relationships, both within and beyond discrete areas and time periods. ${ }^{98}$ Integral to all articulations of MSP is the approach of managing an area or space rather than a sector and typically, the parameters of that area or space is determined by science and constitutes an ecosystem. ${ }^{99}$

\footnotetext{
90 These principles are available at: http://www.helcom.fi/action-areas/maritime-spatial-planning/mspprinciples/; accessed 1 August 2016. The ten principles comprise: sustainable management; ecosystem approach; long term perspective and objectives; precautionary principle; transparency and participation; high quality data and information basis; transnational coordination and consultation; coherent terrestrial and maritime spatial planning; planning adapted to characteristics and special conditions at different areas; and continuous planning.

91 This is available at:

http://www.helcom.fi/Documents/HELCOM $\% 20$ at $\% 20$ work/Groups/MSP/Regional $\% 20$ Baltic $\% 20$ MS P\%20Roadmap\%202013-2020.pdf; accessed 1 August 2016. The Roadmap has been adopted as the HELCOM VASAB MSP 2014 - 2016 work plan available at: http://www.helcom.fi/Documents/HELCOM\%20at\%20work/Groups/MSP/HELCOMVASAB\%20MSP\%20WG\%20Work\%20Plan\%202014-2016.pdf; accessed 1 August 2016.

${ }^{2}$ See for example C Ehler and F Douvere (n 34).

${ }^{93}$ Eg. Directive 2014/89/ EU of the European Parliament and of the Council of 23 July 2014 establishing a framework for marine spatial planning; and The Baltic Principles on MSP available at: These principles are available at: http://www.helcom.fi/action-areas/maritime-spatial-planning/msp-principles/; accessed 1 August 2016.

${ }^{94} \mathrm{G}$ Carneiro (n 1) at p. 214.

${ }^{95} \mathrm{~F}$ Douvere (n 40) at p. 765.

${ }^{96}$ See generally S Kidd and G Ellis, 'From the Land to Sea and Back Again? Using Terrestrial Planning to Understand the Process of Marine Spatial Planning' (2012) 14 Journal of Environmental Policy and Planning 49 66.

${ }^{97}$ RW Duck, 'Marine Spatial Planning: Managing a Dynamic Environment' (2012) 14 Journal of Environmental Policy and Planning $67-79$ at p. 69.

98 S Jay, 'Marine Space: Manoeuvring Towards a Relational Understanding' (2012) 14 Journal of Environmental Policy and Planning $81-96$ at p. 81.

${ }^{99}$ S Jay, G Ellis and S Kidd, 'Marine Spatial Planning: A New Frontier?’ (2012) 14 Journal of Environmental Policy and Planning $1-5$ at p. 4.
} 
Second, MSP is typically developed in response to ecological, social and economic objectives or principles that are determined through some form of political process. ${ }^{100}$ These objectives may be set out in an overarching oceans strategy or policy as in the case of Canada and Australia or they may be developed in a national plan such as the UK's Marine Policy Statement. Australia's 1998 Oceans Policy for example, articulates a series of high level goals including: the exercise and protection of Australia's rights and jurisdiction over offshore resources including rights and obligations under international law; the protection of ecosystems, biological diversity and cultural heritage; the promotion of sustainable development and job creation including facilitating the development of expertise in ocean-related science, technology and engineering; integration of ocean management; accommodation of community needs and aspirations and the promotion of public awareness and understanding. ${ }^{101}$ The Policy goes on to identify principles designed to guide decision-makers in the implementation of these goals: maintenance of ecosystem health; sustainable development of ocean resources, the benefits of which should be shared by all Australians; integrated management; decision-making on the basis of the best scientific information; the precautionary approach; and transparent, participatory processes of planning and resource allocation with minimal regulatory burden. ${ }^{102}$ Canada's 2005 Oceans Strategy sets out a simple over-arching vision: 'to ensure healthy, safe and prosperous oceans for the benefit of current and future generations of Canadians ${ }^{103}$ and articulates a spare triumvirate of principles designed to support the implementation of that vision. These principles comprise sustainable development, integrated management and the precautionary approach. ${ }^{104}$ The UK Marine Policy Statement adopted in 2011 sets out five high level marine objectives: achieving a sustainable marine economy; ensuring a strong, healthy and just society; living within environmental limits; promoting good governance; and using sound science responsibly. ${ }^{105}$ The 11 principles identified in the MPS emphasise the overarching notion of sustainable development, the importance of adaptation, particularly in light of the impacts of climate change and climate change mitigation and the avoidance of harm where possible. ${ }^{106}$ In contrast to Australia and Canada, the UK MPS does not explicitly provide for the precautionary approach but requires that decisions should 'be taken using a risk-based approach that allows for uncertainty, recognising the need to use sound science responsibly. ${ }^{107}$ The development of overarching principles and priorities to underpin MSP facilitates the development and implementation of anticipatory and forward management of activities.

The third principle integral to MSP is the integrated management of multiple activities within an area, space or ecosystem. ${ }^{108}$ Integration seeks to avoid the fragmented sectoral approach to traditional marine management and requires a level of cooperation and coordination between national agencies charged with managing activities such as fishing, minerals exploitation, marine environmental protection and the coastal-marine interface. In some states, such as the UK, a central agency as been established to manage multiple activities, ${ }^{109}$ whilst in others, including Canada, an agency has been created to

\footnotetext{
${ }^{100} \mathrm{C}$ Ehler and F Douvere (n 34) at p. 18.

1011998 Australia's Oceans Policy at p. 4.

1021998 Australia's Oceans Policy at p. 19.

1032005 Canada's Oceans Strategy at p. 10.

1042005 Canada's Oceans Strategy at p. 10.

1052011 UK Marine Policy Statement at pp. 11 - 12.

1062011 UK Marine Policy Statement at p. 14.

107 Ibid.

108 See generally R Barnes (n 35).

109 The Marine Management Organisation (MMO) was created under the 2009 Marine and Coastal Access Act.
} 
coordinate existing government departments and bodies. ${ }^{110}$ In many states, as exemplified by Australia, the coordination role is part of the mandate of an existing government department, ${ }^{111}$ a low-cost option which, however, risks perpetuating the sectoral approach to marine management. The focus on integrated management of multiple activities across sectors ensures that MSP encompasses but is not confined to the narrower concept of area protection through MPA designation. ${ }^{112}$

The fourth principle that underpins MSP is precaution. MSP involves close cooperation with scientists, particularly where it seeks to implement the ecosystem approach to marine management. But knowledge of the oceans is notoriously incomplete and the history of oceans governance is replete with examples of mismanagement resulting from a failure to consider these knowledge gaps whether they relate to the abundance of fish stocks or the impact of climate change on the oceans. ${ }^{113}$ The precautionary principle or approach provides one of the foundations of MSP and typically requires policy-makers to make decisions on the basis of scientific information and to be cautious in the absence of that information.

The precautionary principle also finds support in the penultimate MSP principle, which requires monitoring, review and adaptation of plans in light of new scientific (as well as social) information. Not only is the ocean environment itself physically and temporally dynamic but it is affected by external environmental change, most notably by climate change, as well as by changes in technology. Moreover, MSP must also be able to adapt to changes in values and environmental philosophies as political and governance frameworks shift over time. Provisions for monitoring the environment, review of plans and individual activities and, most importantly, an adaptive approach to planning and management are consequently integral to successful versions of MSP. ${ }^{114}$

The final principle of MSP comprises public engagement. In any context MSP invariably involves a wide range of actors including government departments, regional and local authorities, indigenous groups, commercial, recreational and environmental interests as well as local residents. In order to succeed, MSP must accommodate and respond to these diverse interests.

\section{Assessment of New Zealand Ocean Governance Against the Six Core Criteria of Marine Spatial Planning}

\section{Area-based Ecosystem Management}

In contrast to states leading international practice on MSP such as Australia, Canada and the UK, area-based management in New Zealand covers only around 4 percent of its maritime zone: the territorial sea. The environmental effects of activities out to 12 nautical miles of New Zealand's maritime baselines as well as within its internal waters and coastal environment are subject to regulation under the 1991 Resource Management Act (RMA),

\footnotetext{
${ }^{110}$ Fisheries and Oceans Canada.

111 In Australia this role forms part of the mandate of the Department of the Environment. Originally a separate organisation, the National Oceans Ministerial Board was established to oversea the implementation of Australia's Oceans Policy but this was dissolved in 2004. See M Tsamenyi and R Kenchington ( $\mathrm{n} 45$ ) at p. 127.

112 See generally, GW Allison, J Lubchenco and MH Carr, 'Marine Reserves are Necessary but not Sufficient for Marine Conservation' (1998) 8(1) Supplement: Ecosystem Management for Sustainable Marine Fisheries S79 - 92.

${ }^{113}$ For an engaging history of ocean 'miss-governance' see C Roberts, The Ocean of Life. The Fate of Man and the Sea (Viking, New York, 2012).

114 See generally F Douvere and CN Ehler, 'The importance of monitoring and evaluation in adaptive maritime spatial planning' (2011) 15 J Coast Conserv 305 - 311.
} 
which strongly endorses an ecosystem approach to environmental management within its core objectives. ${ }^{115}$ New Zealand's unicameral political system is far simpler than the federal models that characterise Australia and Canada or even the British system of now highly devolved governance. Nevertheless, New Zealand has a strong history of regional autonomy, and marine and coastal planning within New Zealand's territorial sea is divided between central, regional and local government under the 1991 RMA. The coastal and marine area ${ }^{116}$ is principally managed by seventeen regional councils ${ }^{117}$ and area-based management is thus defined and delimited on the basis of regional political boundaries. Each regional council is responsible for developing a coastal plan for its region ${ }^{118}$ and that plan must be consistent with the principles set out under the 1991 RMA and the New Zealand Coastal Policy Statement (NZCPS) adopted at the national level ${ }^{119}$ and the plan must be approved by the Minister of Conservation. ${ }^{120}$ Although MSP is not specifically identified as a management tool under the RMA, regional plans must nevertheless set out the objectives for the region, policies designed to implement those objectives, rules relating to particular activities designed to achieve those objectives as well as procedures to facilitate cooperation between regional and district authorities. ${ }^{121}$ Strategic planning is further endorsed as a core policy objective in the 2010 NZCPS. ${ }^{122}$

The division of regional jurisdictional boundaries responds in part to catchment areas and thus reflects the broader freshwater/ salt-water ecosystem and the land-sea connection. ${ }^{123}$ The allocation of responsibility for both the terrestrial and the marine environment to regional councils therefore embodies a robust example of integrated coastal management and the RMA has been hailed as a model for ICZM legislation globally. ${ }^{124}$ The ecosystem approach is further emphasised by the broad definition of 'coastal environment', which encompasses any environment in which the coast comprises a significant element or part ${ }^{125}$ and will generally extend to the dominant ridge behind the coast. ${ }^{126}$ The 2010 New Zealand Coastal Policy Statement (NZCPS) provides additional support for the endorsement of the ecosystem approach in regional area management, including within the definition of the coastal environment: 'areas where coastal processes, influences or qualities are significant, including coastal lakes, lagoons, tidal estuaries,

1151991 RMA, section 5(2)(b).

116 The coastal and marine area (CMA) is defined under the RMA as "the foreshore, seabed, and coastal water, and the air space above the water-

(a) of which the seaward boundary is the outer limits of the territorial sea:

(b) of which the landward boundary is the line of mean high water springs, except that where that line crosses a river, the landward boundary at that point shall be whichever is the lesser of -

(i) 1 kilometre upstream from the mouth of the river; or

(ii) the point upstream that is calculated by multiplying the width of the river mouth by

5 .

117 Sixteen regional councils manage the CMA offshore New Zealand and the Chatham Islands Council manages the CMA offshore the Chatham Islands. See:

http://www.localcouncils.govt.nz/lgip.nsf/wpg url/Profiles-Councils-by-Region-index; accessed 1 August 2016. The Department of Conservation performs the functions of regional councils in respect of New Zealand's islands in the subantarctic and the Pacific.

1181991 RMA, section 64 and Schedule 1.

119 These are discussed below.

1201991 RMA, section 28(b).

1211991 RMA, section 67.

1222010 NZCPS, Policy 7.

${ }^{123}$ RA Makgill and HG Rennie, 'A Model for Integrated Coastal Management Legislation: A Principled Analysis of New Zealand's Resource Management Act 1991' (2012) 27 International Journal of Marine and Coastal Law $135-165$ at p. 149.

124 Ibid., at 137.

125 Northland Regional Planning Authority v. Whangarei County (1977) DA 4828 at 4831.

${ }^{126}$ Dudin v. Whangarei District Council NZEnvC Auckland A22/2007, 30 March 2007 at [19]. 
saltmarshes, coastal wetlands, and the margins of these"127 as well as inter-related coastal marine and terrestrial systems, including the intertidal zone. ${ }^{128}$ However, notwithstanding the expansive definition of the coastal environment, the 2010 NZCPS has been criticized for failing to fully capture the 'temporally dynamic, spatially heterogenous, and physically and socially complex' region which characterizes the interface between terrestrial, marine and lacustrine processes. ${ }^{129}$

The region within which ecosystem-based planning is most advanced is the Hauraki Gulf (Tikapa Moana/ Te Moananui-ā-Toi). The Hauraki Gulf Marine Park Act 2000 was adopted for the purposes of designating a marine park in the Gulf, establishing a regional authority, the Hauraki Gulf Forum, to manage the area, and integrating the management of the Gulf, which straddles two regional authorities (Auckland and Waikato). ${ }^{130}$ The impact of the Act, beyond the existing provisions of the RMA, has been subject to criticism ${ }^{131}$ but since 2013 the region has been the subject of concerted and ongoing efforts to develop a marine spatial plan for the Gulf. ${ }^{132}$

Beyond the territorial sea or in the remaining 96 percent of New Zealand's maritime zone, activities are managed on the basis of sector rather than area. Overarching legislation for the EEZ was adopted in 2012 but the Exclusive Economic Zone and Continental Shelf (Environmental Effects) Act (hereinafter, the EEZ Act) was designed to manage the environmental effects of activities not otherwise regulated by existing legislation and does not provide for bioregional planning in the manner of the RMA or indeed as has been developed in other states such as Australia, Canada and the UK. Furthermore, there is, at present, limited scope for basic area protection through the designation of MPAs for purposes other than for fisheries management and marine mammal protection beyond the territorial sea except on an ad hoc basis. ${ }^{133}$ In $2005 \mathrm{New}$ Zealand adopted the Marine Protected Areas Policy and Implementation Plan ${ }^{134}$ with a view to developing a network of MPAs throughout its territorial sea and EEZ. Despite the identification of fourteen biogeographic regions in 2008 and the provision of further guidance ${ }^{135}$ progress has been slow, ${ }^{136}$ hampered particularly by the absence of a clear legislative base for MPA designation. Despite the announcement in late 2015 that an MPA covering 15 percent of New Zealand's EEZ around the Kermandec Islands would be created in 2016 there is little sign that a more principled approach to MPA designation will be adopted throughout New Zealand's maritime zone. It is notable (and lamentable) that

\footnotetext{
1272010 NZCPS, Policy 1, para. (c).

128 Ibid., para. (h).

${ }^{129}$ DE Hart and KR Bryan, 'New Zealand coastal system boundaries, connections and management' (2008) 64 New Zealand Geographer 129 - 143 at p. 129.

${ }^{130}$ Hauraki Gulf Marine Park Act 2000, section 3.

${ }^{131}$ Hauraki Gulf Forum Tikapa Moana, Governing the Gulf. Giving effect to the Hauraki Gulf Marine Park. Act through Policies and Plans (2009) at p. 10.

132 This is discussed further below.

133 The primary legislative instrument that currently permits the designation of marine reserves in New Zealand is the 1971 Marine Reserves Act, which allows reserves to be established within New Zealand's internal waters or territorial sea in order to preserve areas for the purpose of scientific study. Marine mammal sanctuaries anywhere within New Zealand's maritime zone can be established pursuant to the 1978 Marine Mammals Protection Act and areas can be closed for fisheries under sections 186A and 311 of the 1996 Fisheries Act. The first MPA slated for designation in New Zealand's EEZ is the Kermadec Ocean Sanctuary which will cover approximately $620,000 \mathrm{~km}^{2}$. A draft bill is currently before Parliament and the MPA is due to be designated in late 2016.

${ }^{134}$ Department of Conservation and Ministry of Fisheries, Marine Protected Areas Policy and Implementation Plan (2005).

135 Department of Conservation and Ministry of Fisheries, Marine Protected Areas. Classification, Protection Standard and Implementation Guidelines (2008).

136 See generally, SA Banks and GA Skilleter, 'Implementing marine reserve networks: A comparison of approaches in New South Wales (Australia) and New Zealand' (2010) 34 Marine Policy 197 - 207.
} 
Published as The Evolution of Marine Spatial Planning in New Zealand: Past Present and Possible Future" 31 (2016) International Journal of Marine and Coastal Law 652 - 689

proposals to reform and modernise the creation of MPAs, released in early 2016 by the government for example, are confined to the territorial sea only. ${ }^{137}$

\section{Principled and Anticipatory Management}

Typically, MSP has been implemented as part of a broader oceans strategy or policy and is developed within a principled framework. In contrast to other states including Australia, Canada and the UK, New Zealand has yet to develop an overarching oceans strategy, policy or plan. ${ }^{138}$ Moreover, New Zealand lacks unified legislation of application to its entire maritime zone. Nevertheless, both the 1991 RMA, which applies to New Zealand's internal waters and territorial sea and the 2012 EEZ (Environmental Effects) Act, which applies to New Zealand's EEZ and continental shelf are underpinned by mutually supportive principles that are designed to guide marine planning and decision-making and constitute in effect, a basic principled framework for planning and ocean governance more generally.

The overarching objective of the 1991 RMA is the sustainable management of natural and physical resources, which is defined as enabling communities to provide for their social, economic and cultural well-being, whilst protecting the reasonably foreseeable needs of future generations and safeguarding the life-supporting capacity of air, water, soil and ecosystems. ${ }^{139}$ Section 6 of the RMA sets out seven matters of importance that must be recognised and provided for by all persons exercising functions and powers under the Act including authorities responsible for the creation of national, regional and district plans and bodies exercising functions in relation to resource consent applications. These comprise:

(a) the preservation of the natural character of the coastal environment (including the coastal marine area), wetlands, and lakes and rivers and their margins, and the protection of them from inappropriate subdivision, use, and development:

(b) the protection of outstanding natural features and landscapes from inappropriate subdivision, use, and development:

(c) the protection of areas of significant indigenous vegetation and significant habitats of indigenous fauna:

(d) the maintenance and enhancement of public access to and along the coastal marine area, lakes, and rivers:

\footnotetext{
${ }^{137}$ Ministry for the Environment, A New Marine Protected Areas Act: Consultation Document (2016) at p. 12 (hereinafter, MPA Consultation Document (2016)) available at www.mfe.govt.nz; accessed 1 August 2016. See further, KN Scott, 'Evolving MPA Management in New Zealand: Between Principle and Pragmatism' (2016) 47(3) Ocean Development and International Law 289 - 307.

${ }^{138}$ For background to the abandoned attempt to develop a formal oceans policy see Patrick, 'All at Sea: Do We need an Oceans Policy for New Zealand' (2001) IX Resource Management Journal 1 - 5. In 2015, the Ministry of the Environment published a set of environmental goals of application to all environmental media, including the marine environment, focusing on the health, resilience and sustainable development of marine resources but these are underdeveloped and lack a legal foundation. See Ministry of the Environment, A Generation from Now. Our long-term goals. (Wellington, 2015) available at: http://www.mfe.govt.nz/sites/default/files/media/About/generation-from-now-outcomes.pdf; accessed 1 August 2016.

1391991 RMA, section 5. On sustainable management of natural resources and the RMA see D Grinlinton, 'Sustainability in New Zealand Environmental Law and Policy' in P Salmon and D Grinlinton (eds), Environmental Law in New Zealand (Thompson Reuters, Wellington, 2015) 105 - 135 especially pp. $113-121$.
} 
(e) the relationship of Maori and their culture and traditions with their ancestral lands, water, sites, waahi tapu, and other taonga:

(f) the protection of historic heritage from inappropriate subdivision, use, and development:

(g) the protection of protected customary rights.

These matters of national importance have greater weight than regional or district goals and must be meaningfully provided for in national, regional and local plans. It is not sufficient for decision-makers simply to have regard for these factors. ${ }^{140}$ An additional eleven factors that planners and decision-makers must have regard to under the Act are set out in section 7 and include matters relating to environmental and ecosystem quality, the importance of stewardship and the impacts of climate change. Finally, the principles of the Treaty of Waitangi (Te Tiriti o Waitangi) must be taken into account in relation to the management, use, development and protection of natural and physical resources under section 8 of the RMA.

Within the EEZ decision-makers are similarly guided by the principle of sustainable management, defined in similar but not identical terms to section 5 of the RMA. ${ }^{141}$ However, the scope of the EEZ Act is narrower than the RMA and this is relevant to the interpretation of sustainable management under the EEZ Act and a recent decision of the Environmental Protection Authority in connection with an EEZ marine consent application counseled against transferring case law and interpretations uncritically from the RMA to the EEZ Act. ${ }^{142}$ The EEZ Act similarly acknowledges the Crown's obligations under the Treaty of Waitangi with respect to decision-making impacting upon resources. ${ }^{143}$ As noted above, MSP is not provided for beyond New Zealand's territorial sea but the 2012 Act nevertheless sets out a range of principles designed to guide decision-makers, in particular, the Environmental Protection Authority (EPA) when determining marine consent applications. These include the importance of protecting rare or vulnerable ecosystems or species, the economic benefit to New Zealand of the proposed activity as well as the more general principle of efficient use and development of natural resources ${ }^{144}$ and, in contrast to the RMA, an explicit reference to the precautionary principle. ${ }^{145}$

More specifically, within the coastal area and marine environment extending to the outer limit of New Zealand's territorial sea, overarching national priorities and principles have been developed in the New Zealand Coastal Policy Statement adopted in 2010. ${ }^{146}$ The NZCPS is prepared by the Minister of Conservation pursuant to section 28 of the 1991 RMA and, as noted above, must be implemented through regional coastal plans. The 2010 NZCPS places a strong emphasis on precautionary, strategic and integrated management of activities taking place in the $\mathrm{CMA}^{147}$ and sets out 7 objectives and 29 policies, which, in amalgamation, attempt to balance the need for protection and preservation of the coastal and marine environment with economic development in light

\footnotetext{
140 Environmental Defence Society v. Mangonui County Council [1989] 3 NZLR 257, applied in Trio Holdings v. Marlborough District Council [1997] NZRMA 97

1412012 EEZ (Environmental Effects) Act, section 10.

142 Trans-Tasman Resources Ltd Marine Consent Decision, June 2014, [78] available at: http://www.epa.govt.nz/EEZ/EEZ000004/Trans Tasman Resources decision 17June2014.pdf; accessed 1 August 2016.

${ }^{143}$ Ibid., section 12.

${ }^{144}$ Ibid., section 59.

145 Ibid., section 34.

146 The New Zealand Coastal Policy Statement adopted in 2010 is available at: http://www.doc.govt.nz/documents/conservation/marine-and-coastal/coastal-management/nz-coastalpolicy-statement-2010.pdf; accessed 1 August 2016.

${ }^{147}$ Ibid., Policies 3, 4 and 7.
} 
of New Zealand's obligations to its indigenous population and to the international community.

In conclusion, the fundamental principles of sustainable management, precaution and protection of vulnerable ecosystems establish the parameters of planning, and ocean governance more generally. In New Zealand's territorial sea these principles, developed in detail in the NZCPS 2010, inform and underpin regional MSP and, to a significant extent, facilitate forward and anticipatory management of maritime activities, permitting regional authorities to determine, on the basis of the RMA, categories of activities that are prohibited or which require authorisation. ${ }^{148}$ Beyond the slender belt of territorial sea however, a much narrower range of principles are applied by authorities, not in the context of an overall area plan, but as part of individual consent applications. Fundamentally, in contrast to states such as Australia, Canada and the UK, New Zealand lacks overarching principles within a framework applicable to its entire maritime zone.

\section{Integrated Management of Multiple Activities}

Globally, the feature that moves MSP beyond mere area protection is the principle of integrated management. No state has at this stage developed a fully integrated marine management system across all sectors although the UK arguably comes relatively close. Commonly, fisheries are excluded from MSP and are often managed by entirely unconnected agencies or departments. In New Zealand there has been no attempt to date to develop integrated management across its entire maritime zone and, even within the territorial sea, regional planning omits significant sectors such as fishing and conservation through MPAs.

As described above, regional authorities must develop plans for their region consistent with the principles as set out in the 1991 RMA and the 2010 NZCPS. The 1991 RMA, which sets out the overarching framework for all environmental planning in New Zealand territory, including its territorial sea, establishes restrictions and rules relating to the coastal marine area in sections 12,14 and 15 of the Act. Rather than managing activities per se, the 1991 RMA seeks to manage the effects of those activities, and the Act, which when adopted revoked 167 statutes, amended a further 50 statutes and regulations and reduced the number of local government authorities from 700 to $86,{ }^{149}$ was specifically designed to achieve a level of integration across both sectors and agencies. ${ }^{150}$ Moreover, integration across boundaries, sectors and organisations is identified as a core policy objective of the 2010 NZCPS. ${ }^{151}$

Section 12 of the 1991 RMA establishes a presumption against development of the coastal and marine environment except where the development or activity is expressly authorised in a regional coastal plan or by a coastal permit. Activities are designated one of six categories ranging from permitted to prohibited. ${ }^{152}$ Activities classed as permitted do not require a coastal permit provided they comply with any conditions set out in the regional coastal plan. Controlled activities by contrast, must be authorised by a coastal permit but that permit must be issued where the activity complies with any conditions relating to matters over which the control is reserved. Restricted discretionary activities

\footnotetext{
148 This is discussed below.

${ }^{149} \mathrm{R}$ Bess, 'Maintaining a balance between resource utilization and protection of the marine environment in New Zealand' (2010) 34 Marine Policy 690 - 698 at p. 693.

${ }_{150}$ See Bachelor v. Tauranga District Council (No. 2) [1993] 2 NZLR 84 at p. 86. For an overview of the aims and objectives of the 1991 RMA see K Palmer, 'Resource Management Act 1991' in D Nolan (ed), Environmental \& Resource Management Law (4th edition, LexisNexis, Wellington, 2011) at pp. $93-238$. 1512010 NZCPS, Policy 4.

1521991 Resource Management Act, section 87A.
} 
are similarly subject to authorisation via a coastal permit and the power to decline or grant a conditional permit is limited to matters over which the discretion is restricted (as set out in the coastal plan). By contrast, discretionary and non-complying activities must be authorised by a coastal permit and that permit may be declined or subject to any conditions the consent authority deems appropriate. Finally, activities classed as prohibited cannot be authorised by a coastal permit under any conditions. The activities listed in section 12 of the RMA focus on the development of the CMA and include activities such as resource extraction, seabed disturbance and modification, the erection of structures within the CMA and the introduction of species to the CMA. ${ }^{153}$ The discharge of contaminants into the CMA is governed by section 15 of the 1991 RMA and is subject to a similar consent authorisation process.

Linking the process of coastal permits to regional coastal plans as managed by regional authorities under the auspices of one legislative instrument, the RMA, supports a highly integrated approach to the management of coastal and marine activities. As noted above, the jurisdictional reach of regional authorities, which combines the terrestrial and marine environment (out to 12 nautical miles), and will generally coincide with the relevant catchment area, permits a high level of integration in the management of the coast and sea. Although regional coastal plans will necessarily vary in content and regional councils need not be consistent in how activities are designated with respect to the type of permit they need, ${ }^{154}$ the principled framework established by the RMA and the 2010 NZCPS, as well as the requirement that plans are approved by the Minister of Conservation ensures a level of national consistency. Moreover, any activity deemed to be of national significance may be called in by the Minister of Conservation and referred to a Board of Enquiry or the Environment Court for consideration and this provides for a level of national oversight. ${ }^{155}$ Furthermore, the RMA does provide for selected cooperation between interested agencies where that is deemed appropriate. In respect of aquaculture for example, coastal permits authorised under the RMA must be forwarded by the relevant regional authority to the Chief Executive of the Ministry of Fisheries ${ }^{156}$ in order for the Chief Executive to make an assessment on whether the application will have an undue adverse effect on fishing. ${ }^{157}$ Where such a determination is made the coastal permit under the RMA must not be approved unless applicant to agrees to pay compensation to the affected individual. ${ }^{158}$

However, integrated management is limited in two important ways within New Zealand's territorial sea. First, in common with many if not most other jurisdictions,

\footnotetext{
1531991 Resource Management Act, section 12(1) - (6).

${ }^{154}$ For example, regional authorities take quite different approaches to their designation of aquaculture activities in their plans. In the Waikato region all activities associated with aquaculture are designated controlled or discretionary activities (see Waikato Regional Coastal Plan (2011), chapter 16.5.). By contrast, In Northland, existing marine farms or mussel spat collection activities are deemed discretionary but activities associated with new aquaculture applications are designated prohibited activities (see Northland Regional Coastal Plan (2003) [37.7.10 and 31.6.9]). In the Marlborough region aquaculture activities are designated discretionary or restricted discretionary depending on the area in which they are located (Marlborough Regional Plan (2011) [35.2.5 and 35.3.1]) and the Bay of Plenty regional authority has developed a complex hierarchy designating permit status on the basis of whether aquaculture is noncommercial and non-research (a controlled activity), an existing activity (restricted discretionary activity), a new commercial application relating to a zone outside of high value areas and permanently navigable harbour waters (discretionary activity), a new commercial application within permanently navigable waters (non-complying activity) or a new commercial application within high value areas (prohibited activities) (Proposed Bay of Plenty Regional Coastal Environment Plan (2014), section 6.4.).

1551991 RMA, section 142.

1561991 Resource Management Act, section 107.

1571996 Fisheries Act, section 186E.

1581996 Fisheries Act, section 186ZN. Any agreement is normally entered into after arbitration, the process for which is set out under the 1996 Fisheries Act.
} 
fishing is subject to an entirely separate regulatory regime - primarily under the 1996 Fisheries Act - although coastal infrastructure associated with fishing is regulated by the RMA. Similarly, although the environmental effects of oil and gas exploration are subject to RMA jurisdiction, minerals activities are primarily regulated under the 1991 Crown Minerals Act. More surprisingly, and in notable contrast to other jurisdictions, protected area management and the designation of MPAs largely takes place outside of the RMA under separate legislation, principally, the 1971 Marine Reserves Act. There is minimal coordination between the processes of designating marine reserves under the 1971 Act or under separate legislation and marine planning by regional authorities. ${ }^{159}$

Beyond the territorial sea, while, as noted above, there has been no attempt to develop area based or spatial planning in the EEZ, the adoption of the 2012 Exclusive Economic Zone and Continental Shelf (Environmental) Effects Act has permitted the development of a very basic form of partial integrated management. The EEZ Act was developed to complement existing legislation and to fill the very significant gaps in regulating the environmental effects of activities; it was not intended to provide an overarching comprehensive regulatory regime for the EEZ. It does not therefore manage fisheries, the allocation of oil and gas permits (although as under the RMA, it does seek to manage and mitigate the environmental impacts of these activities) or shipping. ${ }^{160}$ Rather than integrate these separate regimes, their relationships are mediated and delimited by the Act in an attempt to minimise jurisdictional overlap. ${ }^{161}$ Nonetheless, the Act provides a mandate for one agency, the Environmental Protection Authority (EPA) ${ }^{162}$ to decide marine consent applications, to enforce the Act and to promote public awareness of the Act. ${ }^{163}$ Similar to the RMA, activities are categorised under the 2012 Act as permitted, discretionary and prohibited. ${ }^{164}$ Permitted activities do not require a permit provided they comply with the terms of any regulations and, if required by the regulations, are notified to the EPA. ${ }^{165}$ Discretionary activities including any activity which disturbs the seabed, involves resource extraction, construction or the introduction of species ${ }^{166}$ or the discharge of harmful substances or waste from structures at sea ${ }^{167}$ must be authorised by a marine consent and are either notified or non-notified. As described above, the EEZ Act sets out a number of principles and matters to be considered by the EPA when considering consent applications and, in with a nod to the ecosystem approach, the EPA must also consider the impacts of activities on the territorial sea and coastal environment. ${ }^{168}$ Furthermore, the EPA must similarly take into account other legislation such as the 1991 RMA and any

\footnotetext{
159 In early 2016 the government released a consultation document setting out a proposal for a new Marine Protected Area Act, consolidating and updating existing regulation relating to MPAs. However, the proposal is confined to the territorial sea only and does not address in detail integration with regional plans and the RMA. See Ministry for the Environment, A New Marine Protected Areas Act: Consultation Document (2016) at 12 (hereinafter, MPA Consultation Document (2016)) available at www.mfe.govt.nz; accessed 1 August 2016. See further, KN Scott (n 137).

160 Shipping is largely managed by the 1994 Maritime Transport Act.

${ }^{161}$ For example, in 2015 the 2012 EEZ Act was amended to clarify that the 2012 Act governed discharges and dumping from structures and the Maritime Transport Act 1994 regulates discharges and dumping from ships (section 20A 2012 EEZ Act).

162 Established by the Environmental Protection Authority Act 2011.

1632012 EEZ Act, section 13.

1642012 EEZ Act, sections 35 - 37.

1652012 EEZ Act, section 35. Permitted activities are set out in The EEZ (Environmental Effects Permitted Activities) Regulations 2013 and include marine research, activities affecting permitted marine structures, seismic surveying and activities relating to submarine cables.

1662012 EEZ Act, section 20.

1672012 EEZ Act, sections 20A - 20I.

168 Trans-Tasman Resources Ltd. (n 141) at [107].
} 
other applicable marine management regimes ${ }^{169}$ when considering consent applications and this provision has been used by the EPA as a basis to consider the implications of an activity for the 2010 NZCPS and regional plans although the EPA has acknowledged that neither the NZCPS nor regional plans have direct application to the EEZ. ${ }^{170}$ The final point to note is that although section 28 of the EEZ Act permits regulations to be adopted to identify and close areas to activities that are important or especially vulnerable owing to their biophysical characteristics or environmental pressures or because they are likely to be the subject of conflicting activities, the Act does not provide for the designation of MPAs. Moreover, as discussed above, there is currently no overarching regime facilitating MPA designation on a principled and ecologically coherent basis within the EEZ. ${ }^{171}$

\section{Precaution}

The precautionary approach or principle typically underpins most versions of MSP (with the exception of the UK) and is an important principle in the context of oceans governance in New Zealand. Although the 1991 RMA does not expressly endorse the precautionary approach as a guiding principle as such, precaution is nevertheless regarded as inherent within the Act. ${ }^{172}$ The precautionary principle was however, expressly adopted in the New Zealand 2010 Environment Strategy adopted in $1995^{173}$ and is identified as a key principle in the 2010 NZCPS. ${ }^{174}$ Policy 3 of the NZCPS requires decision-makers to 'adopt a precautionary approach towards proposed activities whose effects on the coastal environment are uncertain, unknown, or little understood, but potentially significantly adverse.' Therefore in developing regional plans and in determining consent applications in respect of the marine environment, regional authorities must interpret their obligations under the RMA so as to apply the precautionary principle.

Moreover, the concept of precaution has received implicit endorsement in an important 2014 decision of the New Zealand Supreme Court in its interpretation of two 2010 NZCPS policies. ${ }^{175}$ Policies 13(1)(a) and 15(a), which require activities and development to avoid adverse effects on the outstanding national character of the coastal environment and on outstanding natural features and landscapes of the coastal environment respectively, were held by the Supreme Court to operate as 'environmental bottom lines', which must be given effect to by regional authorities in their plans and coastal consent decision-making. The approach of the High Court, which 'balanced' any adverse effects on outstanding character, features and landscapes with the social gains arising from development - in this particular case, the expansion of marine farms - was dismissed by the Supreme Court in favour of an approach which characterised the requirement to avoid adverse effects as an environmental bottom line not to be transgressed, even for economic gain.

In contrast to the RMA, the precautionary principle is expressly endorsed in the 2012 EEZ Act in section 34(2), which stipulates, 'if, in relation to the making of a decision under this Act, the information available is uncertain or inadequate, the Minister must favour caution and environmental protection'. In the relatively few consent applications

\footnotetext{
1692012 EEZ Act, section 59(2) (h) and $(\mathrm{k})$ - (m).

170 Trans-Tasman Resources Ltd. (n 141) at [754].

171 See discussion at note 159 and accompanying text, above.

172 Shirley Primary School v Christchurch City Council [ 1999] NZRMA 66 (EnvC) at 69; Golden Bay Marine

Farmers v Tasman District Council EnvC Christchurch W42/2001. See generally A Gillespie, 'Precautionary

New Zealand' (2011) 24 New Zealand Universities Law Review 364 - 385 especially at pp. 374 - 376.

173 Ministry for the Environment Environment 2010 Strategy: A Statement of the Govemment's Strategy on the

Environment (1995).

1742010 NZCPS, Policy 3.

175 Environment Defence Soc Inc. v. The New Zealand King Salmon Co Ltd \& Ors [2014] NZSC 38.
} 
considered by the Environmental Protection Authority (EPA) thus far in respect of the EEZ, the Authority has adopted a robust application of the precautionary principle. In two marine consent applications associated with seabed mining activities in 2014 and 2015 respectively for example, the EPA dismissed the applications largely on the basis that inadequate information had been provided in relation to the likely environmental impacts of the operations. ${ }^{176}$

\section{Review, Monitoring and Adaptive Management}

An adaptive approach to planning and management, incorporating review and monitoring is essential to MSP. ${ }^{177}$ Although the RMA sets out detailed processes for the preparation, review and change of regional coastal plans ${ }^{178}$ it lacks specificity around the obligations to regularly monitor and assess the plan itself in contrast to obligations to monitor and assess individual activities. In respect of individual activities and the process of marine consents within both the territorial sea and the EEZ however, the principle of adaptive management has recently received unequivocal endorsement by the New Zealand Supreme Court and by the EPA. ${ }^{179}$

Notably, in New Zealand, adaptive management has developed in the context of the precautionary principle and is therefore largely confined to consideration as part of the decision-making process to issue a marine consent for an activity when information is incomplete or uncertain. Section 61(3) of the 2012 EEZ Act stipulates: 'if favouring caution and environmental protection means that an activity is likely to be refused, the EPA must first consider whether taking an adaptive management approach would allow the activity to be undertaken.' Adaptive management itself is defined in section 64(2) as:

(a) allowing an activity to commence on a small scale or for a short period so that its effects on the environment and existing interests can be monitored:

(b) any other approach that allows an activity to be undertaken so that its effects can be assessed and the activity discontinued, or continued with or without amendment, on the basis of those effects.

The EPA in implementing an adaptive management approach may require the activity to be undertaken in stages and may impose conditions relating to monitoring and reporting prior to the authorization of other stages of the activity. ${ }^{180}$ A 'stage' may relate to the duration of the consent, an area, or the scale, intensity or nature of the activity. ${ }^{181}$ More generally, the EPA has conceded that an alternative conception of adaptive management, specifically, a process focused on monitoring the whole activity, the identification of trigger

\footnotetext{
176 Trans-Tasman Resources Ltd (n 141) at [129 - 139] and Chatham Rock Phosphate Lt Marine Consent Decision, February 2015, [816 - 827] available at: http://www.epa.govt.nz/EEZ/previous-activities/notifiedconsents/chatham rock phosphate/decision/Pages/CRP decision.aspx; accessed 1 August 2016. See also DK Anton and RE Kim, 'Current Legal Developments New Zealand. The Application of the Precautionary and Adaptive Management Approaches in the Seabed Mining Context: Trans-Tasman Resources Ltd Marine Consent Decision under New Zealand's Exclusive Economic Zone and Continental Shelf (Environmental Effects) Act 2012' (2015) 30 The International Journal of Marine and Coastal Law 175 188

177 F Douvere and CN Ehler (n 114) at p. 305.

1781991 RMA, Schedule 1.

${ }^{179}$ See Sustain our Sounds Inc. v. New Zealand King Salmon Company [2014] NZSC 40; Trans Tasman Resources Ltd (n 142); Chatham Rock Phosphate (n 176).

1802012 EEZ Act, Section 64(3).

1812012 EEZ Act, Section 64(4).
} 
indicators or values to allow the assessment of whether the overall environmental objectives are being met and the adaption of management to meet those objectives, would also be consistent with section 64(2)(b) of the 2012 EEZ Act. ${ }^{182}$ Nevertheless, as conceived in the 2012 EEZ Act, adaptive management is apparently constrained by its explicit link to the precautionary principle and its ostensible purpose of providing a basis to allow activities to go ahead in circumstances when the application of the precautionary principle would otherwise prevent the EPA issuing a marine consent.

Adaptive management is not expressly incorporated into the 1991 RMA or the 2010 NZCPS. However, in an important decision of the New Zealand Supreme Court, Sustain our Sounds Inc. v. New Zealand King Salmon Company, in 2014, adaptive management was explicitly endorsed as a management approach that, if implemented, would permit a consent to be issued in respect of marine farm expansion where information relating to the impact of that expansion on water quality was incomplete. ${ }^{183}$ The Supreme Court concluded that adaptive management supported the application of the precautionary approach as set out in Policy 3 of the 2010 NZCPS ${ }^{184}$ and cited international authority, including the 2007 IUCN Guidelines, ${ }^{185}$ as well as New Zealand and international case law to this effect. ${ }^{186}$ With respect to the threshold as to when an adaptive management regime can be considered the Court stipulated that 'there must be an adequate evidential foundation to have reasonable assurance that the adaptive management approach will achieve its goals of sufficiently reducing uncertainty and adequately managing any remaining risk. ${ }^{, 187}$ The Court went on to say: ${ }^{188}$

The secondary question of whether the precautionary approach requires an activity to be prohibited until further information is available, rather than an adaptive management or other approach, will depend on an assessment of a combination of factors:

a) the extent of the environmental risk (including the gravity of the consequences if the risk is realised);

(b) the importance of the activity (which could in some circumstances be an activity it is hoped will protect the environment);

(c) the degree of uncertainty; and

(d) the extent to which an adaptive management approach will sufficiently diminish the risk and the uncertainty.

Finally, the Court noted that in respect of the question of whether the 'extent to which an adaptive management appproach will sufficiently diminish the risk and uncertainty' ${ }^{189}$ will

182 Trans Tasman Resources Ltd (n 142) at [797]. The EPA concluded however, that the process of adaptive management put forward by Trans Tasman in this case was insufficient to address the uncertainties associated with the environmental impacts of iron sand mining in the case. Support for the position that adaptive management could be defined in ways other than that set out in section 61(3) and 64 of the 2012 EEZ Act as also stated in Chatham Rock Phosphate (n 176) at [832].

183 Sustain our Sounds Inc. v. New Zealand King Salmon Company [2014] NZSC 40. See generally V Rive, 'Adaptive Management in the Supreme Court: Sustain Our Sounds Inc v. The New Zealand King Salmon Company Ltd’ (2014) 10 BRMB 137.

184 Sustain our Sounds Inc. v. New Zealand King Salmon Company [2014] NZSC 40 at [107].

185 IUCN, Guidelines for applying the precautionary principle to biodiversity conservation and natural resource management as approved by the $67^{\text {th }}$ meeting of the IUCN Council, $14-16$ May 2007. Sustain our Sounds Inc. v. New Zealand King Salmon Company [2014] NZSC 40 at [109].

186 Sustain our Sounds Inc. v. New Zealand King Salmon Company [2014] NZSC 40 at [113 - 123].

187 Ibid., at [125].

${ }^{188}$ Ibid., at [129].

${ }^{189}$ Ibid., at [129(d)]. 
depend on the extent of the risk, the extent of the uncertainty and the gravity of the consequences if the risk is realised. ${ }^{190}$ In particular, when addressing this question the Court asserted that four factors were particularly relevant: good baseline information; effective monitoring using appropriate indicators; the identification of thresholds to trigger remedial action before the effects become overly damaging and; the ability to remedy effects before they become irreversible. ${ }^{191}$ The approach and reasoning of the Supreme Court in Sustain our Sounds has been broadly adopted and applied by the EPA in two cases where information about the impact of prospective mining activities in the EEZ was incomplete. ${ }^{192}$ However, in the Chatham Rock Phosphate consent application the EPA cautioned that the test developed by the Supreme Court in Sustain Our Sounds is arguably dissimilar to that set out in section 61(3) of the 2012 EEZ Act and as such 'an adaptive management approach is not inherently inconsistent with favouring caution and environmental protection, and therefore the particular threshold question addressed by the Court in [Sustain our Sounds] may be unnecessary. ${ }^{193}$ The EPA went onto say 'that essentially, is why staging is a reasonably fundamental aspect of adaptive management. It recognises that certain effects may arise and be addressed at a future time; and puts in place objectives, thresholds, responses, triggers, limits, standards, restart parameters, and so on, precisely to allow that decision point to be deferred to a future time but within the ambit of the consent granted. ${ }^{194}$ Nevertheless, the EPA emphasised that it did not call into question the Supreme Court's broader findings on adaptive management and noted that it found the various factors set out by the Court as as 'both appropriate and helpful to its inquiry. ${ }^{.195} \mathrm{In}$ both Trans Tasmen and Chatham Rock Phosphate adaptive management was not considered appropriate by the applicants as in the former case the applicant asserted that the whole area for the whole duration needed to be mined to be commercially viable ${ }^{196}$ and in the latter case the applicant was not prepared to undertake the pre-mining research and in situ moddelling required. ${ }^{197}$

Adaptive management as developing in New Zealand consequently seeks to bridge the divide between the objectives of conservation and economic development, which are embedded within both the 1991 RMA and the 2012 EEZ Act. Although consents typically require conditions to be met in respect of monitoring impact and environmental change, adaptive management more generally is not applied as a general principle to all activities. Rather, its application is more narrowly confined to activities the impact of which is uncertain in order to mitigate the impact of the precautionary principle. Its contemporaenous consideration and application by the Supreme Court and the EPA in relation to the territorial sea and EEZ respectively has facilitated the development of a relatively integrated approach in the development of adaptive mangement across New Zealand's entire maritime zone. However, its application to activities more generally and, just as importantly, to regional planning is thus far limited.

\section{Public Engagement}

The final principle relates to public engagement in the MSP processes. Traditionally, New Zealand has a strong track record in relation to consultation and the inclusion of diverse

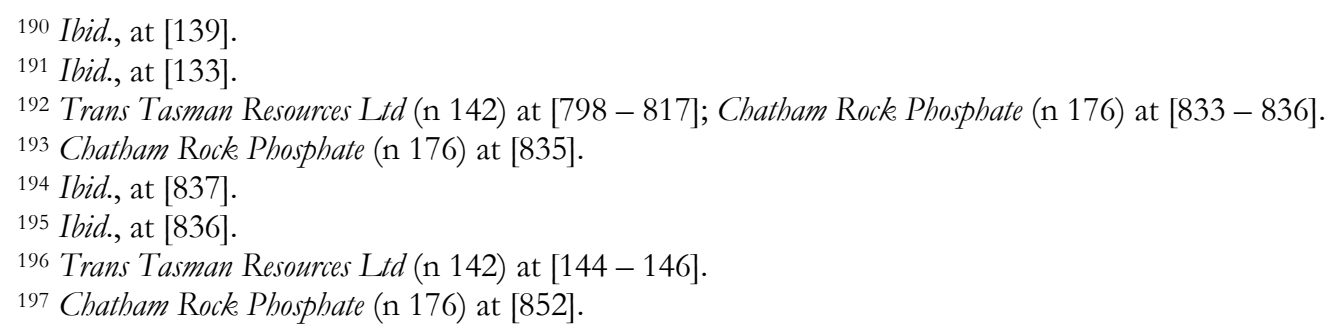


groups, including iwi and mana whenua in decision-making relating to the marine environment. The very significant discord between the Crown and Māori over the status of the foreshore and seabed in the early $2000 \mathrm{~s}^{198}$ has largely been resolved with the passing of the Marine and Coastal Area (Tukutai Moana) Act in 2011, which declared that the foreshore and seabed - referred to for the purposes of the Act as the 'common marine and coastal area (CMCA)' - could not be owned by the Crown or any other person ${ }^{199}$ but could be subject to selected rights including a form of customary title. ${ }^{200}$ This does not mean of course that tensions do not arise, as illustrated by the decision of Te Ohu Kaimoana (Te Ohu), the Maori Fisheries Commission in 2016 to challenge the government's decision to establish the Kermadec Ocean Sanctuary in the High Court on the basis that it allegedly compromises Te Ohu fishing rights under the 1992 fisheries settlement between the Crown and Māori and that there has been insufficient consultation with Māori during the decision-making process to establish the MPA. ${ }^{201}$ Despite these occasional public disagreements, detailed processes for consultation are provided for within the 1991 RMA in relation to the development of the national coastal policy statement, ${ }^{202}$ regional coastal plans ${ }^{203}$ as well as in connection with individual consent applications. ${ }^{204}$ Similarly, the 2012 EEZ Act provides for processes facilitating consultation and challenge associated with marine consent applications. ${ }^{205}$

Furthermore, in at least three regions marine management is in fact driven by collaborative, inclusive local organisations. As will be discussed further below ${ }^{206}$ the Hauraki Gulf Forum was established under the 2000 Hauraki Gulf Marine Park Act and comprises 21 members drawn from national government, local authorities and tangata whenua. The Forum is designed to provide for the integrated management of the Hauraki Gulf. ${ }^{207}$ And in an initiative with entirely grassroots origins a collective of fishers, conservationists, recreational users, tourist operators and local iwi came together in 1995 to form the Guardians of Fiordland Fisheries and their organisation was re-named the Fiordland Marine Guardians and given a statutory basis in the Fiordland (Te Moona o Atawhenua) Marine Management Act 2005. The Fiordland Guardians operate as an

\footnotetext{
198 In Attorney General v. Ngati Apa [2003] 3 NZLR 643 (CA) the New Zealand Court of Appeal overturned legal precedent dating back to 1877 (Wi Parata v. Bishop of Wellington (1877) 3 NZ Jur (NS) (SC)) and determined that Māori customary title to the foreshore and seabed had not been extinguished by legislation adopted after the 1840 Treaty of Waitangi and that it was open, in principle, for the Māori Land Court to determine the validity of individual claims to the foreshore and seabed. This decision was almost immediately reversed by the New Zealand government through its adoption of the controversial Foreshore and Seabed Act in 2004, which vested ownership of the foreshore and seabed in the Crown. The 2004 Act was ultimately repealed in 2011. On the foreshore and seabed debate see D Grinlinton, 'Private Property Rights versus Public Access: The Foreshore and Seabed Debate' (2003) 7 New Zealand Journal of Environmental Law 313 - 341; J Ruru, 'The Political and Juridical Battle in the Salt-sand Environment' in J Ruru, J Stephenson and M Abbott (eds), Making our place: exploring land-use tensions in Aotearoa New Zealand (Otago University Press, Otago, 2011) 23 - 38

1992011 Marine and Coastal Area (Tukutai Moana) Act, section 11(2).

2002011 Marine and Coastal Area (Tukutai Moana) Act, sections 47 - 50, 51, 58 - 50. See generally, A Suszko, 'The Marine and Coastal Area (Takutai Moana) Act 2011: A Just and Durable Solution to the Foreshore and Seabed Debate?' (2012) 25 New Zealand Universities Law Review 148 - 179.

${ }^{201}$ See: http://www.nzherald.co.nz/nz/news/article.cfm?c id=1\&objectid=11522838; accessed 1 August 2016.

2021991 RMA, sections 57 and $46-46$ A.

2031991 RMA, sections 64 and Schedule 1.

2041991 RMA, Part 6.

2052012 EEZ Act, Part 3, subpart 2 and Part 4.

206 See Section 6, below.

2072000 Huaraki Gulf Marine Park Act, Part 2. See generally: http://www.aucklandcouncil.govt.nz/en/aboutcouncil/representativesbodies/haurakigulfforum/pages/h ome.aspx\#members; accessed 1 August 2016.
} 
advisory board, promoting integrated management of the region and have a mandate to monitor compliance with and enforcement of the local marine management regime. ${ }^{208} \mathrm{~A}$ similar advisory role has been developed for the Kaikoura Marine Guardians, comprising representatives from Te Rūnanga o Ngāi Tahu, the Kaikōura community as well as from sectors with an interest in biosecurity, conservation, education, environment, fishing, marine science and tourism in relation to the Kaikōura region under the Kaikōura (Te Tai o Marokura) Marine Management Act 2014. ${ }^{209}$ A risk associated with the development of local organisations is that they may favour or be dominated by particular sector interests and a challenge in respect of both Fiordland and Kaikōura has been managing fishery with other interests.

\section{Concluding Remarks and Select Recommendations}

Globally, MSP is becoming an increasingly dominant approach to managing marine activities within the jurisdiction of states, although as Stephen Jay et al have pointed out: 'MSP processes are not developing in a consistent manner in line with expert recommendations, but are dependent on varying national and even sub-national, political, geographical and socio-economic contexts. ${ }^{210}$ In New Zealand, contrary to the global trend however, MSP is not endorsed or implemented at the national level across its maritime zone. In contrast to states such as Australia, Canada and the UK, New Zealand lacks overarching legislation of application to its entire marine environment, has eschewed the development of a national oceans policy or plan and has no national coordinating agency with responsibility for all - or most - things maritime.

This does not mean however, that New Zealand's approach to ocean governance is entirely unplanned or unintegrated. An assessment of New Zealand practice against the six core principles that typically underpin MSP globally reveals that the foundations for developing MSP have already been laid. Under the 1991 RMA New Zealand was in fact one of the first states to adopt area-based regional planning for its coastal environment and territorial sea and even today demonstrates leadership in the integrated management of the coastal/ marine interface. The principles for ocean management developed under the 1991 RMA, the 2010 NZCPS and the 2012 EEZ Act are compatible and mutually supportive and collectively combine to form something approaching an overarching principled framework for oceans governance. The adoption of a single act to manage most - but by no means all - activities within the territorial sea, the 1991 RMA, facilitates a good level of integration in the management of diverse activities. Although by contrast, activities are managed on the basis of sector within the EEZ, the creation of an overarching agency, the EPA, to consider applications in respect of most - but again, not all - activities supports a basic level of integrated management beyond the territorial sea. In common with other jurisdictions, New Zealand has developed a relatively robust approach to the precautionary principle, the implementation of which has recently been supported by the identification of 'environmental bottom lines' and the development of the concept of adaptive management as a means to facilitate activities where information about their effects is incomplete. Finally, New Zealand has developed processes for public consultation at every stage of oceans management, from the development of plans to challenging marine consents.

The legislative and policy foundations that underpin at least the principles of MSP are demonstrated in the first attempt to develop a marine spatial plan for a region: the

${ }^{208}$ Fiordland (Te Moona o Atawhenua) Marine Management Act 2005, Part 3. See generally:

http://www.fmg.org.nz/content/story-guardians; accessed 1 August 2016.

${ }^{209}$ Kaikōura (Te Tai o Marokura) Marine Management Act 2014, Part 2.

210 S Jay, W Flannery, J Vince et al (n 41) at p. 206. 
Hauraki Gulf (Tikapa Moana (also known as Te Moananui-ā-Toi)). The Hauraki Gulf covers two regional authorities, surrounds New Zealand's largest city - Auckland - and is subject to multiple competing terrestrial and marine pressures. ${ }^{211}$ In response to these very particular regional conditions the Hauraki Gulf Marine Park Act was adopted in 2000. The Act established the Hauraki Gulf Marine Park, created the Hauraki Gulf Forum, a management authority comprising national regional, local and iwi representatives and was designed to coordinate existing entities and provide for fully integrated management of the catchment, coastal area and marine environment. Although the principles of the Act are deemed to be equivalent of principles contained in the 2010 NZCPS and therefore must be given effect to by regional planners and decision-makers, ${ }^{212}$ courts have struggled to apply them, particularly where they apparently conflict with RMA principles. ${ }^{213}$ Nevertheless, following a 2011 report exploring the potential for MSP within the Hauraki Gulf region $^{214}$ a partnership was established in 2013, named Sea Change - Tai Timu Tai Pari, comprising mana whenua with customary authority over the area, Auckland Council, Waikato Regional Council, the Department of Conservation, the Ministry for Primary Industries and the Hauraki Gulf Forum, to develop a marine spatial plan for the Gulf. ${ }^{215}$ Progress has been relatively slow but the Independent Review Panel (IRP) established to assess work completed to date, in their first report, praised the 'exciting and visionary process' and the high standard of work done to date. ${ }^{216}$ More cautiously, in their second report released in 2015, the IRP noted that few aspirational goals for the region has been identified thus far and that MSP itself was significantly under-developed. ${ }^{217}$ The Marine Spatial Plan for the Hauraki Gulf is due to be completed in 2016.

Despite this positive progress at a regional level, New Zealand more generally, is falling behind international best practice and risks losing its position as a traditional leader in the field of oceans governance. As described above, 96 percent of New Zealand's maritime zone is not subject to a planning regime and significant areas of marine governance including fisheries and MPA designation are located beyond the processes of integrated governance that have been developed. In order to address some of these issues and to build upon the foundations of MSP already laid by existing legislative and policy frameworks there are a number of initiatives that could be developed by New Zealand of varying levels of ambition. These are sketched out in very brief terms below.

${ }^{211}$ Hauraki Gulf Forum, Governing the Gulf: Giving Effect to the Hauraki Marine Park. Act through Policy and Plans (2009) (hereinafter, Governing the Gulf) at p. 10 available at:

bttp:// www.auck.landcouncil.govt.nz/EN/AboutCouncil/ representativesbodies/ haurakigulfforum/Documents/Governing \%20the $\% 20$ Gulf $\% 20$ Giving $\% 20$ Effect $\% 20$ to $\% 20$ the $\% 20$ Hauraki $\% 20$ Gulf $\% 20$ Marine $\% 20$ Park $\% 20$ Act $\% 20$ through \%20Policies\%20and\%20Plans.pdf; accessed 1 August 2016.

2122000 Hauraki Gulf Marine Park Act, section 9.

${ }^{213}$ See particularly Long Bay-Okura Great Park Society v. North Shore City Council A078/2008, 16 July 2016. For discussion of the impact of the 2000 Hauraki Gulf Marine Park Act principles and, in particular, differences between the Act and the RMA, see Hauraki Gulf Forum, Governing the Gulf (n 211) at pp. 33 46.

${ }^{214}$ Huaraki Gulf Forum, Spatial Planning for the Gulf: An International Review of Marine Spatial Planning Initiatives and Application to the Hauraki Gulf (2011) available at:

http:// www.aucklandcouncil.govt.nq/SiteCollectionDocuments/aboutcouncil/committees/baurakigulfforum/meetings/ haura kigulfforumagitem15att20110411.pdf; accessed 1 August 2016.

215 For information on this process see: http://www.seachange.org.nz; accessed 1 August 2016.

216 Independent Review Panel, Te Timu Tai Pari Sea Change. Hauraki Gulf Marine Spatial Plan First Review Report (August 2014) at 3. Available at:

http://www.seachange.org.nz/PageFiles/500/IRP\%20first $\% 20$ review\%20report.pdf; accessed 1 August 2016.

217 Independent Review Panel, Te Timu Tai Pari Sea Change. Hauraki Gulf Marine Spatial Plan Second Review Report (March 2015) at 3 and 4. Available at:

http://www.seachange.org.nz/PageFiles/500/Independent $\% 20$ Review $\% 20$ Panel $\% 20$ second $\% 20$ report $\% 2$ 0March\%202015.pdf; accessed 1 August 2016. 
First, and with relative ease, New Zealand could adopt an overarching set of principles, goals and objectives applicable to its entire maritime zone. The basis of what effectively constitutes an 'oceans policy' has already been developed through the RMA, EEZ Act, 2010 NZCPS and even the recent set of non-statutory environmental goals published by the Ministry of the Environment in 2015. ${ }^{218}$ The desire for additional principled guidance, particularly within the EEZ, has already been demonstrated by the EPA in the Trans Tasman Resources Ltd where the Authority relied on the 2010 NZCPS to provide guidance in assessing a marine consent application notwithstanding that its terms are not directly applicable to the EEZ. ${ }^{219}$ Building on existing principles and guidelines, which apply primarily - but not exclusively - to the territorial sea, the development of overarching goals and principles to New Zealand's maritime zone would support greater integration of management and improve planning.

A second initiative, which is similarly achievable, is to adopt legislation permitting the designation of MPAs within New Zealand's entire maritime zone on a principled basis. Currently, the primary instrument for MPA designation is the 1971 Marine Reserves Act, the scope of which is restricted to the territorial sea. MPAs designed to protect marine mammals or manage fisheries throughout New Zealand's maritime zone more generally are provided for under other legislation. ${ }^{220}$ In 2005 the government adopted a Marine Protected Areas Policy and Implementation Plan, ${ }^{221}$ which was designed to support the creation of a network of MPAs throughout New Zealand's entire maritime zone, but progress has been slow with MPAs being under ad hoc special legislation rather than within a principled framework. ${ }^{222}$ A reform proposal released by the government in early 2016 seeks to create updated and unified legislation for MPAs but surprisingly, the proposal confines new legislation to the territorial sea only. ${ }^{223}$ Area protection is fundamental to any system of MSP and a first step towards a more sophisticated system of oceans governance comprises developing a principled approach to area protection throughout New Zealand's entire maritime zone.

More ambitiously, an initiative which would require significant government resources, comprises the development of a process of spatial planning for the EEZ. As in the case of the territorial sea, the development of marine plans, in conjunction with a binding set of principles and policy objectives would provide a firm, principled basis on which to make decisions with respect to individual activities. This initiative would require however, investment in science to provide appropriate baseline data, investment in institutions to manage the planning process and investment in legislative reform to provide a statutory basis for such plans and to enable for integrated coordination with regional authorities and the management of the territorial sea.

The most ambitious initiative would seek to effect a root and branch reform of the current legislative framework in New Zealand in order to develop an integrated, unified legislative framework for New Zealand's entire maritime zone. This would be a major undertaking requiring significant reform to the 1991 RMA, the 2012 EEZ Act as well as numerous other Acts - including potentially the 1996 Fisheries Act - and the creation of a new government agency to manage all marine matters. Such a proposal is reminiscent

218 Ministry of the Environment, A Generation from Now. Our long-term goals. (Wellington, 2015) available at: http://www.mfe.govt.nz/sites/default/files/media/About/generation-from-now-outcomes.pdf; accessed 1 August 2016.

219 Trans Tasman Resources Ltd (n 142) at [745 and 760].

${ }^{220}$ Marine Mammals Protection Act 1978, section 22; Fisheries Act 1996, sections 186A and 311.

221 Department of Conservation and Ministry of Fisheries, Marine Protected Areas Policy and Implementation Plan (2005).

${ }^{222}$ For an overview of New Zealand's MPA legislation and progress to date see KN Scott (n 137).

${ }^{223}$ Ministry for the Environment, A New Marine Protected Areas Act: Consultation Document (2016) (n 136).

For a critique of this proposal see KN Scott (n 137). 
of the reforms adopted in 2009 in the UK and arguably go someway beyond the institutions and processes developed in Australia, Canada and elsewhere.

Given New Zealand's economic constraints it is unlikely that the third and fourth options identified above are feasible or, in light of the actual pressures on New Zealand's marine environment, necessarily desirable. However, serious consideration should be given to the first two options: the development of a set of overarching principles and goals (effectively an oceans policy) and the development of a fully integrated MPA strategy applicable across New Zealand's maritime zones. Both these initiatives would strengthen the foundations of MSP already laid and support future developments. In particular, they, along with the existing legislative framework - primarily comprising the 1991 RMA and the 2012 EEZ Act - would provide a basis for the development of MSP on a regional/ sub-regional basis. The development of a marine spatial plan for the Hauraki Gulf, driven primarily by the Hauraki Gulf Forum arguably provides a realistic precedent for the development of similar plans by other regional organisations such as the Fiordland Marine Guardians and the Kaikōura Marine Guardians, both of which have a statutory basis and a management mandate in respect of Fiordland and Kaikōura respectively. With a stronger, overarching set of principles, goals and objectives agreed nationally and better integration of at least area management, the current legislative framework is arguably sufficient to permit, with government encouragement and support, the development of marine spatial planning on an ad hoc regional basis, at least for the time being. 